Jurnal Kependudukan Indonesia | Vol. 14 No. 2 Desember 2019| 93-104

JURNAL KEPENDUDUKAN INDONESIA

p-ISSN : 1907-2902 (Print)
e-ISSN : 2502-8537 (Online)

\title{
STUDI JUMLAH ANAK YANG DIINGINKAN \\ DALAM PERSPEKTIF MAKRO SOSIO-EKONOMI DI INDONESIA
}

\author{
(STUDY OF DESIRED NUMBER OF CHILDREN \\ IN THE MACRO SOCIO-ECONOMIC CONTEXT IN INDONESIA)
}

\author{
Sisilia Nurteta \\ BPS Provinsi Jambi \\ Korespondensi penulis: sisilia@bps.go.id
}

\begin{abstract}
Having a lot of children requires costs for fulfilling clothes, food, health, education and entertainment needs. Nowadays, families put more consideration at the value of children in terms of quality, not just quantity. The value of children is related to the number of children desired that mainly influenced by micro-level factors in the household. Nevertheless, there are indications that macro socio-economic factors also influence the number of desired fertility. This study uses correlation analysis to see the relationship between the average number of wanted children and macro variables such as contraceptive use, human development index (HDI), income per capita, proportion of poor population, age of first marriage, expenditure per capita per year, and woman's work participation. The results show that the variables of contraceptive use, HDI, percentage of poor people, expenditure per capita, and female labour participation rate are statistically proven to affect the average number of desired children, while the variable income per capita and age at first marriage are not statistically significant. This study argued that the number of desired children is not only influenced by household micro variables but also socio-economic macro variables.
\end{abstract}

Keywords: value of children, desired number of children, fertility, cost of children

\begin{abstract}
Abstrak
Memiliki anak yang banyak berarti membutuhkan banyak biaya untuk pemenuhan sandang, pangan, kesehatan, pendidikan dan hiburan. Pada masa sekarang, keluarga lebih memandang nilai anak yang dimiliki, lebih kepada kualitas bukan hanya kuantitas. Nilai anak ini berkaitan dengan jumlah anak yang diinginkan yang kebanyakan dipengaruhi oleh faktor mikro dalam rumah tangga. Namun, terdapat indikasi bahwa faktor makro sosio-ekonomi turut memberikan pengaruh terhadap jumlah anak yang diinginkan. Kajian ini menggunakan analisis korelasi untuk melihat hubungan antara rata-rata jumah anak yang diinginkan dengan variabel makro seperti penggunaan kontrasepsi, indeks pembangunan manusia (IPM), pendapatan per kapita, persentase penduduk miskin, usia kawin pertama dan pengeluaran perkapita per tahun di Indonesia. Dari hasil analisis korelasi yang dilakukan, variabel penggunaan kontrasepsi, IPM, persentase penduduk miskin, pengeluaran perkapita dan tingkat partisipasi angkatan kerja (TPAK) perempuan terbukti secara statistik memengaruhi rata-rata jumlah anak yang diinginkan, sedangkan variabel pendapatan per kapita dan usia kawin pertama tidak terbukti secara statistik mempengaruhi. Penelitian ini menemukan bahwa penentuan jumlah anak yang diinginkan tidak hanya dipengaruhi variabel mikro rumah tangga, tetapi juga variabel makro sosioekonomi.
\end{abstract}

Kata kunci: nilai anak, jumlah anak yang diinginkan, kelahiran, biaya anak 
Jurnal Kependudukan Indonesia | Vol. 14, No. 2, Desember 2019|93-104

\section{PENDAHULUAN}

Angka kelahiran di Indonesia mengalami fluktuasi yang signifikan dari tahun ke tahun. Pada tahun 1970-an, hasil Sensus Penduduk tahun 1971 menunjukkan angka kelahiran total (TFR) sebesar 5,61. Hal ini berarti bahwa rata-rata jumlah anak yang dimiliki berkisar antara 5-6 orang (BPS, 2018a). Fenomena ini terus mengalami penurunan hingga tahun 1994. Hasil Survei Demografi dan Kesehatan Indonesia (SDKI) menunjukkan bahwa TFR pada tahun 1994 tercatat sebesar 2,85, yang berarti rata-rata jumlah anak yang dimiliki menjadi hanya 2-3 orang (BPS, 2018a).

Pada masa baby boom di tahun 1970-an, jumlah kelahiran bayi sangat tinggi. Untuk mengatasi hal ini, pemerintah menggalakkan program Keluarga Berencana (KB) untuk menekan laju pertumbuhan penduduk Indonesia. Penurunan drastis yang terjadi secara terus menerus tersebut merupakan salah satu bentuk keberhasilan pemerintah dalam menggalakkan program KB (Heryanah, 2015). Pandangan banyak anak banyak rejeki secara perlahan mulai bergeser ke arah keluarga kecil bahagia sejahtera (Siregar, 2003). Dengan adanya keyakinan bahwa anak sebagai masa depan keluarga, dalam perkembangan selanjutnya, tiap keluarga dituntut untuk memiliki rencana dalam meningkatkan kualitas hidup anak. Dengan kata lain kualitas anak lebih dipandang penting daripada jumlah anak. Keluarga lebih mengedepankan kesejahteraan, pendidikan dan kesehatan anak. Semakin banyak anak yang dimiliki, semakin besar biaya yang diperlukan, termasuk biaya kesehatan, pendidikan, hiburan, dan lainnya.

Perkembangan zaman semakin modern dan tuntutan globalisasi mulai merubah gaya hidup masyarakat Indonesia sampai ke pelosok wilayah. Peran keluarga menjadi semakin penting, tidak ada lagi batasan antara peran ayah dan ibu, keduanya berperan bersama, bahkan sampai bertukar peran. Tuntutan gaya hidup ini mulai menyulitkan keluarga dengan jumlah anak yang banyak. Memiliki jumlah anak yang banyak berarti membutuhkan banyak biaya untuk pemenuhan sandang, pangan, kesehatan, pendidikan dan juga hiburan (National Research Council, 1983). Jika pada zaman dahulu nilai anak lelaki lebih tinggi daripada anak perempuan, maka untuk masa sekarang tidak ada lagi perbedaan antara nilai anak laki-laki dan perempuan. Sama halnya dengan anak laki-laki, pendidikan, kesehatan dan segala kebutuhan anak perempuan menjadi sama pentingnya. Nilai anak dapat ditinjau dari berbagai segi, yaitu dalam segi agama, sosial, ekonomi dan psikologis (Ihromi, 1999). Nilai anak dari segi agama dianggap bahwa anak adalah titipan Tuhan yang harus dirawat dan dijaga, sedangkan dalam kehidupan sosial, tampak dalam hal anak berperan sebagai penerus keturunan dan ahli waris.

Dari sisi ekonomi, anak dipandang sebagai aset yang berperan dalam memberikan bantuan ekonomis kepada orang tua, baik berupa bantuan tenaga kerja maupun materi. Sementara itu, nilai anak dari segi psikologis dapat bernilai positif maupun negatif. Nilai positif termasuk anak dapat memberikan perasaan aman, bangga, puas, memberikan dorongan dan semangat kerja, serta menghangatkan keluarga. Sebaliknya nilai negatifnya anak juga menimbulkan perasaan was-was, khawatir, repot, kurang bebas, dan lain-lain (Ihromi, 1999). Jumlah anak yang diinginkan dan nilai anak terbukti positif saling memengaruhi (National Research Council, 1982). Jumlah anak yang diinginkan tersebut disesuaikan dengan keperluan anak di masa depan, pendapatan orang tua dan biaya pemeliharaan anak (Kashalala \& Koch, 2014). Walaupun demikian, terdapat indikasi bahwa pembangunan sosio ekonomi memiliki pengaruh negatif terhadap jumlah anak yang dimiliki (Bongaarts, 1993).

Hasil SDKI menunjukkan bahwa TFR Indonesia sebesar 2,6 pada tahun 2012, kemudian mengalami penurunan hingga sebesar 2,4 pada tahun 2017 (BKKBN, BPS, Kementerian Kesehatan, \& USAID, 2018). TFR atau angka kelahiran total adalah rata-rata jumlah anak yang dilahirkan seorang wanita selama masa usia suburnya. TFR Indonesia pada tahun 2017 adalah sebesar 2,4, hal ini berarti rata-rata jumlah anak yang dilahirkan oleh wanita di Indonesia berkisar antara 2-3 orang anak. Dari angka ini, dapat digambarkan bahwa wanita usia subur di Indonesia memiliki tidak hanya dua anak, tapi banyak juga yang memiliki tiga anak, bahkan jika dilihat menurut provinsi, ada yang memiliki 4 anak. Selain angka kelahiran total (TFR), SDKI juga menghasilkan TFR yang diinginkan, angka ini menggambarkan rata-rata jumlah anak ideal yang diinginkan selama masa usia suburnya. Perbandingan antara jumlah kelahiran dan jumlah anak yang diinginkan terlihat pada Gambar 1. 
Gambar 1. Angka kelahiran total dan angka fertilitas yang diinginkan menurut provinsi di Indonesia, 2017

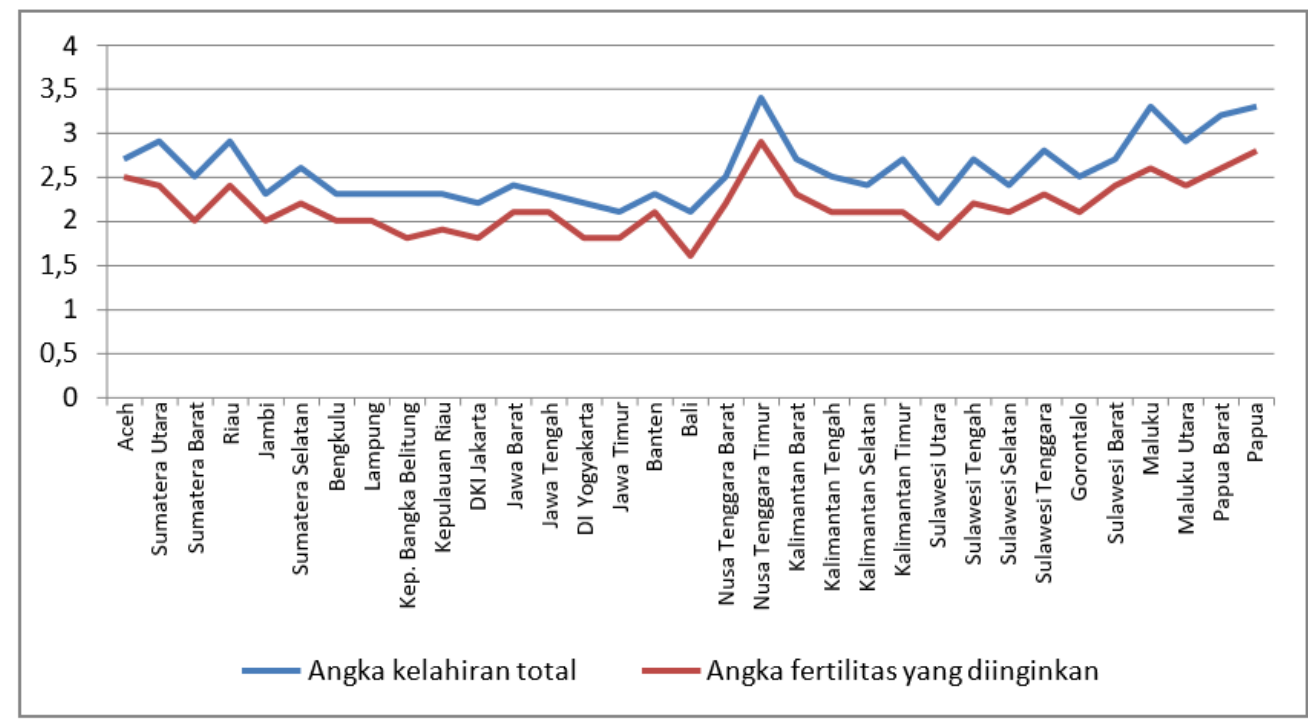

Sumber: BPS (2018a)

Dari Gambar 1 terlihat bahwa wanita di Indonesia umumnya menginginkan jumlah anak sebanyak 2 orang. Dilihat per provinsi, jumlah anak yang diinginkan terbanyak terdapat di Nusa Tenggara Timur (NTT) sebesar 2,9 atau sekitar 3 orang. Di saat yang sama, jumlah anak yang dimiliki saat ini adalah sebesar 3,4 atau berkisar 3-4 orang anak. Di Provinsi Papua, rata-rata jumlah anak yang diinginkan sebesar 2,8, sementara jumlah anak yang dimiliki saat ini adalah sebanyak 3,3 atau berkisar antara 3-4 orang anak. Di Maluku dan Papua Barat, jumlah anak yang diinginkan sebesar 2,6, sedangkan jumlah anak yang dimiliki saat ini adalah sebesar 3,3 dan 3,2. Jika jumlah anak yang diinginkan ini dibandingkan dengan jumlah anak yang dimiliki pada masing-masing provinsi, maka didapatkan kesimpulan bahwa semua wanita di seluruh provinsi di Indonesia menginginkan jumlah anak yang lebih rendah dibandingkan dengan jumlah anak yang dimiliki saat ini. Hal ini menandakan adanya anak yang tidak diinginkan atau dapat dikatakan anak yang tidak direncanakan (unwanted fertility). Hal ini sejalan dengan penelitian Bongaarts (1993) yang mengatakan bahwa angka fertilitas total terdiri dari kelahiran yang diinginkan dan kelahiran yang tidak diinginkan.

Kelahiran yang tidak diinginkan ini merupakan akibat kebutuhan ber-KB yang belum terpenuhi (unmet need), yang tercatat sebesar 10,6\% (BKKBN, BPS, Kementerian Kesehatan, \& USAID, 2018). Unmet need menandakan kondisi tidak terpenuhinya hak reproduksi perempuan karena ketidakmampuan mereka menggunakan kontrasepsi. Hal ini dapat dikarenakan antara lain pasangan usia subur (PUS) yang tidak ingin menggunakan alat kontrasepsi, PUS yang tidak menginginkan anak lagi, atau PUS yang ingin menjarangkan kehamilan (Putro \& Listyaningsih, 2017).

Faktor utama yang memengaruhi permintaan anak menurut National Research Council (1982) adalah biaya langsung dan keuntungan dari memiliki anak, biaya kesempatan yang hilang karena memiliki anak, selera atau preferensi pribadi terhadap anak, efek pendapatan dan kekayaan, serta pengalaman merawat anak. Di samping itu, seiring dengan pergeseran zaman, pola komunikasi dalam keluarga masa kini cenderung lebih terbuka, termasuk dalam perencanaan dan membangun keluarga. Misalnya dalam hal menentukan jumlah anak, semakin tinggi pendidikan, semakin terbuka sikapnya dalam membicarakan hal itu dengan pasangannya. Demikian juga halnya dengan pandangan mengenai penggunaan alat kontrasepsi dalam keluarga. Dengan demikian, pelaksanaan program KB telah berhasil membentuk pola pikir masyarakat utamanya mengenai pemahaman tentang jumlah anak yang pantas bagi keluarganya (Fatchiati, 2015). Jika pada masa lalu, ada anggapan bahwa banyak anak banyak rejeki, karena adanya harapan bahwa anak akan dapat membantu orang tua dalam memperoleh penghasilan. Hal ini menyebabkan pendidikan anak menjadi hal yang sering terabaikan, apalagi untuk anak perempuan yang hanya dipersiapkan untuk menjadi istri yang hanya bertugas sebagai ibu rumah tangga saja. 
Masih terbatasnya penelitian yang mengkaji variabel jumlah anak yang diinginkan dilihat dari faktor-faktor makro di bidang sosial ekonomi di Indonesia mendorong perlunya dilakukan penelitian untuk melihat hubungan antara faktor-faktor makro sosial ekonomi dan rata-rata jumlah anak yang diinginkan. Secara khusus, artikel ini bertujuan untuk mengidentifikasi faktor-faktor yang ikut memengaruhi rata-rata jumlah anak yang diinginkan, menganalisis pengaruh faktor penggunaan alat kontrasepsi, pendapatan per kapita, pengeluaran per kapita, indeks pembangunan manusia (IPM), persentase penduduk miskin, dan usia kawin pertama terhadap rata-rata jumlah anak yang diinginkan.

\section{METODOLOGI}

Penelitian ini menggunakan analisis korelasi untuk melihat hubungan antara masing-masing variabel makro sosio-ekonomi dan rata-rata jumah anak yang diinginkan. Variabel makro sosio-ekonomi yang diikutkan dalam penelitian ini adalah variabel penggunaan kontrasepsi, IPM, pendapatan per kapita, persentase penduduk miskin, usia kawin pertama, dan pengeluaran per kapita per tahun. Ruang lingkup dalam penelitian ini adalah 33 provinsi di seluruh Indonesia, kecuali Kalimantan Utara karena keterbatasan data. Data-data makro sosio-ekonomi dalam penelitian ini seluruhnya diambil dari data Badan Pusat Statistik (BPS). Data angka penggunaan kontrasepsi (CPR), median usia kawin pertama dan rata-rata jumlah anak yang diinginkan menurut provinsi diambil dari hasil pendataan SDKI tahun 2017 (BKKBN, BPS, Kementerian Kesehatan, \& USAID, 2018). Data pendapatan per kapita diambil dari data Produk Domestik Regional Bruto atas dasar harga berlaku tahun 2017 (BPS, 2018b) dibagi dengan jumlah penduduk provinsi hasil proyeksi SP2010 untuk tahun 2017 (Bappenas, BPS, \& UNFPA, 2013). Data IPM menurut provinsi merupakan hasil penghitungan dengan melibatkan tiga dimensi penting dalam pembangunan yakni dimensi kesehatan, dimensi pendidikan dan dimensi eknomi (BPS, 2018c). Dimensi kesehatan yang dimaksud adalah angka harapan hidup saat lahir (AHH). AHH ini mencerminkan derajat kesehatan suatu masyarakat. Selanjutnya, dimensi pendidikan adalah faktor rata-rata lama sekolah dan angka harapan lama sekolah. Dimensi ekonomi adalah pengeluaran per kapita yang disesuaikan didapat dari nilai pengeluaran per kapita dan paritas daya beli (purchasing power parityPPP). Untuk data persentase penduduk miskin (BPS, 2018d) dan data pengeluaran perkapita per tahun (BPS, 2018e) diambil dari hasil pendataan Survei sosial ekonomi nasional (SUSENAS) yang dilaksanakan pada bulan Maret 2017 dengan memperhitungkan pengeluaran makanan dan non makanan dari semua kelompok komoditas makanan. Semua variabel yang digunakan merupakan variabel numerik.

Semua variabel tersebut dianalisis dengan terlebih dahulu menghitung besaran korelasi tiap variabel makro sosio-ekonomi terhadap rata-rata jumlah anak yang diinginkan rumah tangga. Analisis korelasi bivariate Pearson dilakukan untuk melihat seberapa kuat pengaruh suatu variabel terhadap variabel lain, serta untuk melihat arah pengaruhnya, positif atau negatif. Positif berarti variabel bergerak ke arah yang sama, sedangkan negatif berarti kedua variabel bergerak ke arah yang berlawanan. Analisis selanjutnya adalah dengan melakukan analisis deskriptif untuk melihat pengaruhnya secara luas. Berikut adalah rumus korelasi Pearson (Burns, 1939) yang digunakan yaitu:

$$
r=\frac{\sum x y-\frac{\left(\sum x\right)\left(\sum y\right)}{n}}{\sqrt{\left(\sum x^{2}-\frac{\left(\sum x\right)^{2}}{n}\right)\left(\sum y^{2}-\frac{\left(\sum y\right)^{2}}{n}\right)}}
$$

Keterangan:

r: korelasi Pearson antara variabel $\mathrm{x}$ dan $\mathrm{y}$; bernilai $-1 \leq \mathrm{r} \leq 1$ tanda (+) dan (-) menandakan arah hubungan

$\mathrm{n}$ : jumlah sampel $\mathrm{x}=$ nilai variabel $\mathrm{X}, \mathrm{y}=$ nilai variabel $\mathrm{Y}$

\section{HASIL DAN PEMBAHASAN}

\section{Gambaran umum rata-rata jumlah anak yang diinginkan}

Data jumlah anak yang diinginkan diambil dari SDKI 2017, pertanyaan ini diajukan kepada semua wanita dan wanita pernah kawin usia 15 sampai 49 tahun. Untuk penelitian ini, data yang diambil adalah pernyataan dari wanita pernah kawin karena wanita yang sudah pernah kawin berarti sudah sangat mengerti tentang nilai anak yang akan menjadi tanggungannya. Hasil yang didapat adalah bahwa jumlah anak yang diinginkan berkisar antara 1,6 anak sampai 2,9 anak. Rata-rata jumlah anak yang diinginkan di Indonesia adalah sebanyak 2,1 anak, yang berarti sebagian besar wanita pernah kawin menginginkan anak 2 orang. Hal ini berarti sesuai dengan target BKKBN yang menargetkan TFR sebesar 2,1 pada tahun 2025 (BKKBN, 2015). Provinsi dengan 
rata-rata jumlah anak yang diinginkan paling sedikit adalah di Bali yaitu sebanyak 1,6 anak, diikuti oleh Bangka Belitung, DKI Jakarta, DI Yogyakarta, Jawa Timur dan Sulawesi Utara sebanyak 1,8 anak. Sementara itu, provinsi dengan jumlah anak yang diinginkan terbanyak adalah Papua sebesar 2,8 anak dan Nusa Tenggara Timur sebesar 2,9 anak.

\section{Penggunaan kontrasepsi}

Angka prevalensi kontrasepsi di Indonesia secara ratarata mencapai $63,6 \%$. Jika dilihat menurut provinsi, beberapa provinsi dengan persentase penggunaan kontrasepsi di atas 70\% adalah DI Yogyakarta (76\%), Kalimantan Tengah (73,2\%), Kepulauan Bangka
Belitung (71,1\%), dan Bengkulu (70,5\%) (BKKBN, BPS, Kementerian Kesehatan, \& USAID, 2018). Banyaknya wanita yang menjadi peserta KB merupakan salah satu indikator keberhasilan program $\mathrm{KB}$ dalam menekan laju pertumbuhan penduduk sekaligus mewujudkan masyarakat yang sejahtera dan berkualitas (Hartoyo dkk., 2011).

Jika dibandingkan antara variabel penggunaan kontrasepsi dan jumlah anak yang diinginkan terlihat bahwa jika penggunaan kontrasepsi tinggi maka jumlah anak yang diinginkan semakin sedikit. Sebaliknya, jika penggunaan kontrasepsi rendah maka jumlah anak yang diinginkan banyak (Gambar 2).

Gambar 2. Persentase pengguna kontrasepsi dan rata-rata jumlah anak yang diinginkan menurut provinsi, Indonesia, 2017

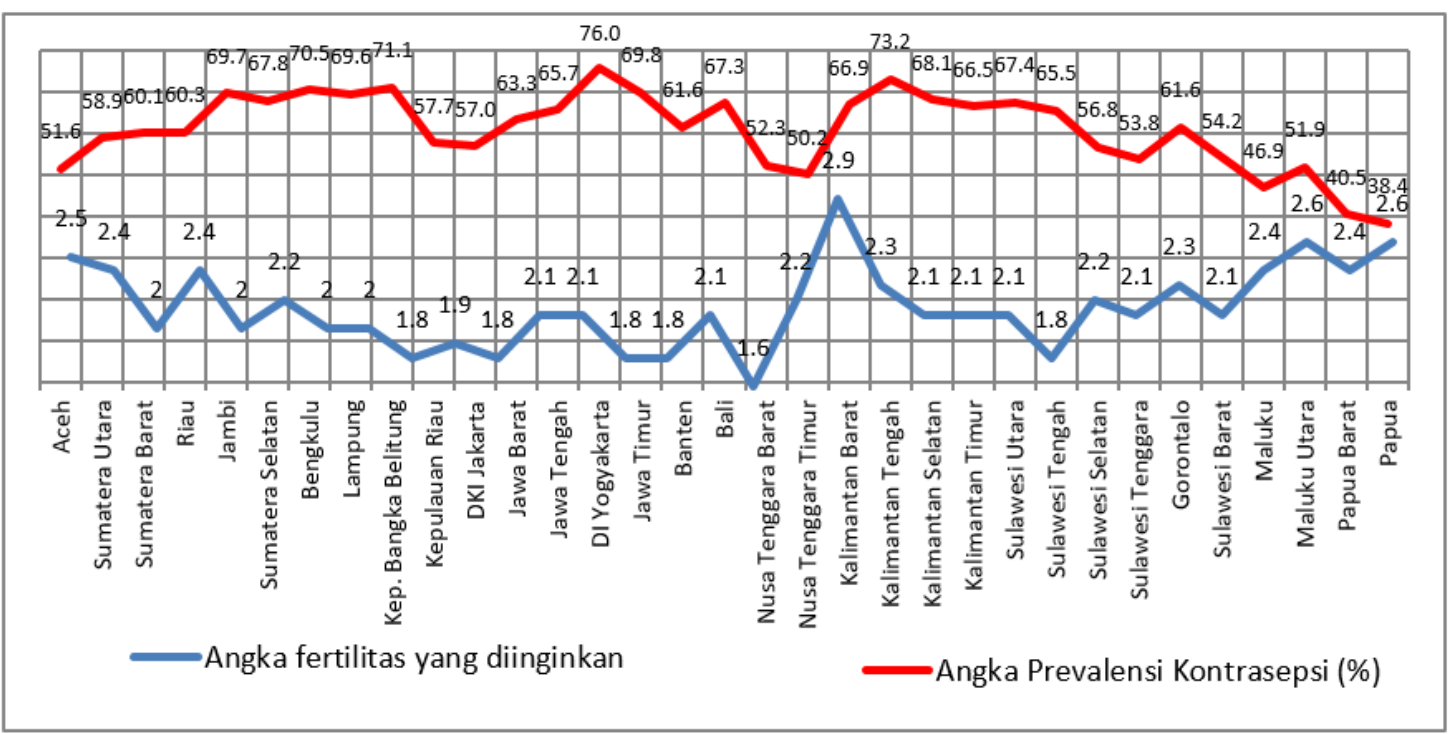

Sumber: BPS (2081a)

Dari analisis korelasi Pearson (Tabel 1), tampak bahwa hubungan antara variabel jumlah anak yang diinginkan dan variabel penggunaan kontrasepsi sangat kuat dan signifikan.

Tabel 1. Hasil analisis korelasi Pearson antara penggunaan kontrasepsi dan rata-rata jumlah anak yang diinginkan

\begin{tabular}{|c|c|}
\hline Korelasi Pearson & $\begin{array}{c}\text { Rata-rata jumlah anak } \\
\text { yang diinginkan }\end{array}$ \\
\hline Penggunaan kontrasepsi & $\begin{array}{c}\mathrm{r}=-0,755 \\
\text { sign }=0,000\end{array}$ \\
\hline
\end{tabular}

Arah hubungan yang bersifat negatif menandakan bahwa jika terjadi penambahan jumlah anak yang diinginkan maka persentase penggunaan kontrasepsi mengalami penurunan, demikian juga sebaliknya. Hal ini berarti bahwa untuk menurunkan jumlah anak yang diinginkan adalah dengan meningkatkan persentase penggunaan kontrasepsi. Dapat disimpulkan bahwa variabel penggunaan kontrasepsi merupakan salah satu faktor yang ikut menentukan jumlah anak yang diinginkan. Alat kontrasepsi dijadikan sebagai salah satu cara untuk mengatur jumlah anak, baik jumlah anak yang dimiliki maupun jumlah anak yang diinginkan, sebab kontrasepsi dapat digunakan untuk membatasi sekaligus menjarangkan kehamilan.

\section{Pendapatan per kapita}

PDRB (Produk Domestik Regional Bruto) per kapita yang digunakan dalam penelitian ini merupakan proxy 
atau pendekatan dari variabel pendapatan per kapita. PDRB per kapita dapat dimaknai sebagai nilai tambah yang dihasilkan oleh masing-masing penduduk di suatu wilayah dalam kurun waktu satu tahun. BPS (2018f) menggambarkan bahwa DKI Jakarta adalah wilayah dengan PDRB per kapita tertinggi dibandingkan dengan provinsi lain di Indonesia, yaitu sebesar 228,0 juta rupiah per tahun. Namun TFR di wilayah ini justru sangat rendah yaitu 2,2 anak, bahkan jumlah anak yang diinginkan hanya 1,8 anak. Kondisi lain terjadi di Nusa Tenggara Timur, PDRB per kapita di wilayah ini merupakan PDRB per kapita terendah namun TFR di wilayah ini sangat tinggi hingga mencapai 3,4. Gambaran mengenai variabel pendapatan per kapita dan jumlah anak yang diinginkan terlihat pada Gambar 3.

Gambar 3. Pendapatan per kapita dan rata-rata jumlah anak yang diinginkan menurut provinsi, Indonesia, 2017

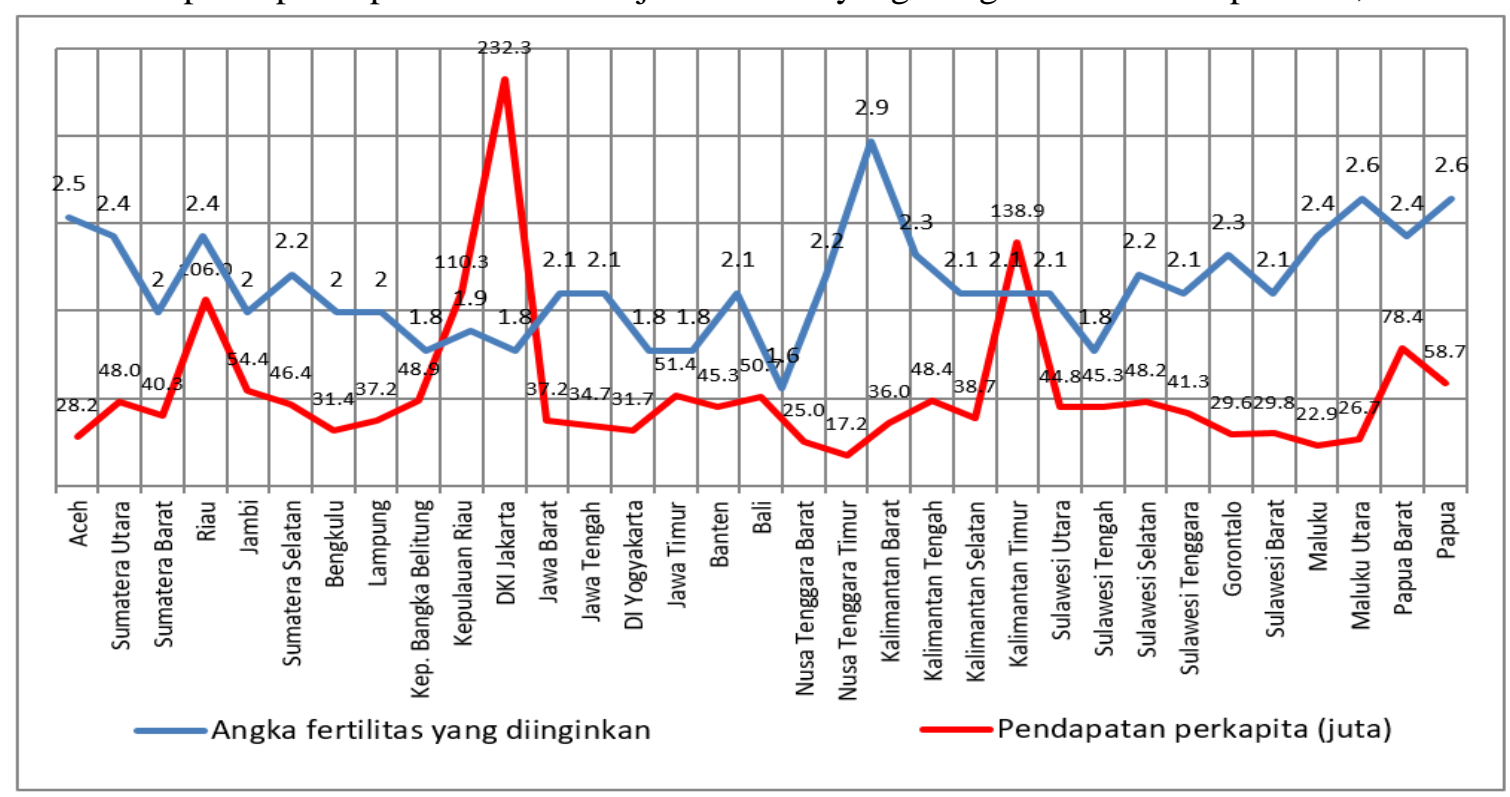

Sumber: BPS (2018a, 2018f)

Apabila dilihat dari hasil analisis korelasi Pearson (Tabel 2), dapat dijelaskan bahwa kedua variabel ini terbukti tidak signifikan saling memengaruhi. Hal ini dikarenakan variabel pendapatan per kapita merupakan variabel makro yang mencerminkan pembangunan ekonomi secara luas bukan hanya dari pendapatan rumah tangga saja, sedangkan pertimbangan untuk memiliki anak merupakan keputusan rumah tangga.

Tabel 2. Hasil analisis korelasi Pearson antara pendapatan per kapita dan rata-rata jumlah anak yang diinginkan

\begin{tabular}{|c|c|}
\hline Korelasi Pearson & $\begin{array}{c}\text { Rata-rata jumlah anak } \\
\text { yang diinginkan }\end{array}$ \\
\hline Pendapatan per kapita & $\begin{array}{c}\mathrm{r}=-0,244 \\
\text { sign }=0,171\end{array}$ \\
\hline
\end{tabular}

Dengan kata lain, pendapatan per kapita bukan merupakan faktor yang dapat menentukan jumlah anak yang ingin dimiliki suatu rumah tangga. Pendapatan per kapita disini merupakan akumulasi pendapatan nasional yang didistribusikan secara menyeluruh ke seluruh penduduk Indonesia menurut provinsi masing-masing, mencakup seluruh nilai tambah barang dan jasa dari seluruh unit produksi di semua lapangan usaha yang ada di Indonesia (BPS, 2018g) dan bukan pendapatan yang hanya diterima rumah tangga.

\section{Pengeluaran per kapita per tahun}

Berbeda dengan pendapatan per kapita, variabel pengeluaran per kapita per bulan merupakan variabel yang benar-benar mencerminkan biaya yang dikeluarkan oleh rumah tangga. Namun, elemen di dalam variabel ini tidak hanya meliputi pengeluaran untuk biaya anak, tetapi juga termasuk seluruh kelompok komoditas yaitu rata-rata pengeluaran per kapita dibagi rata-rata total pengeluaran perkapita dikali seratus persen (BPS, 2018f). Jika dibandingkan secara deskripif antara variabel pengeluaran per kapita per tahun dan variabel rata-rata jumlah anak ideal yang diinginkan, terlihat bahwa pola dari kedua variabel cenderung tidak terstruktur (Gambar 4). Sebagai contoh, Aceh memiliki pengeluaran per kapita per tahun rendah, tetapi rata-rata jumlah anak yang diinginkan justru tinggi, Sementara itu, Lampung memiliki pengeluaran per kapita per tahun 
rendah dan rata-rata jumlah anak yang diinginkan juga rendah. Contoh lainnya adalah DKI Jakarta memiliki pengeluaran per kapita per tahun sangat tinggi namun justru rata-rata jumlah anak yang diinginkan sangat rendah.

Gambar 4. Pengeluaran per kapita per tahun dan rata-rata jumlah anak yang diinginkan menurut provinsi, Indonesia, 2017

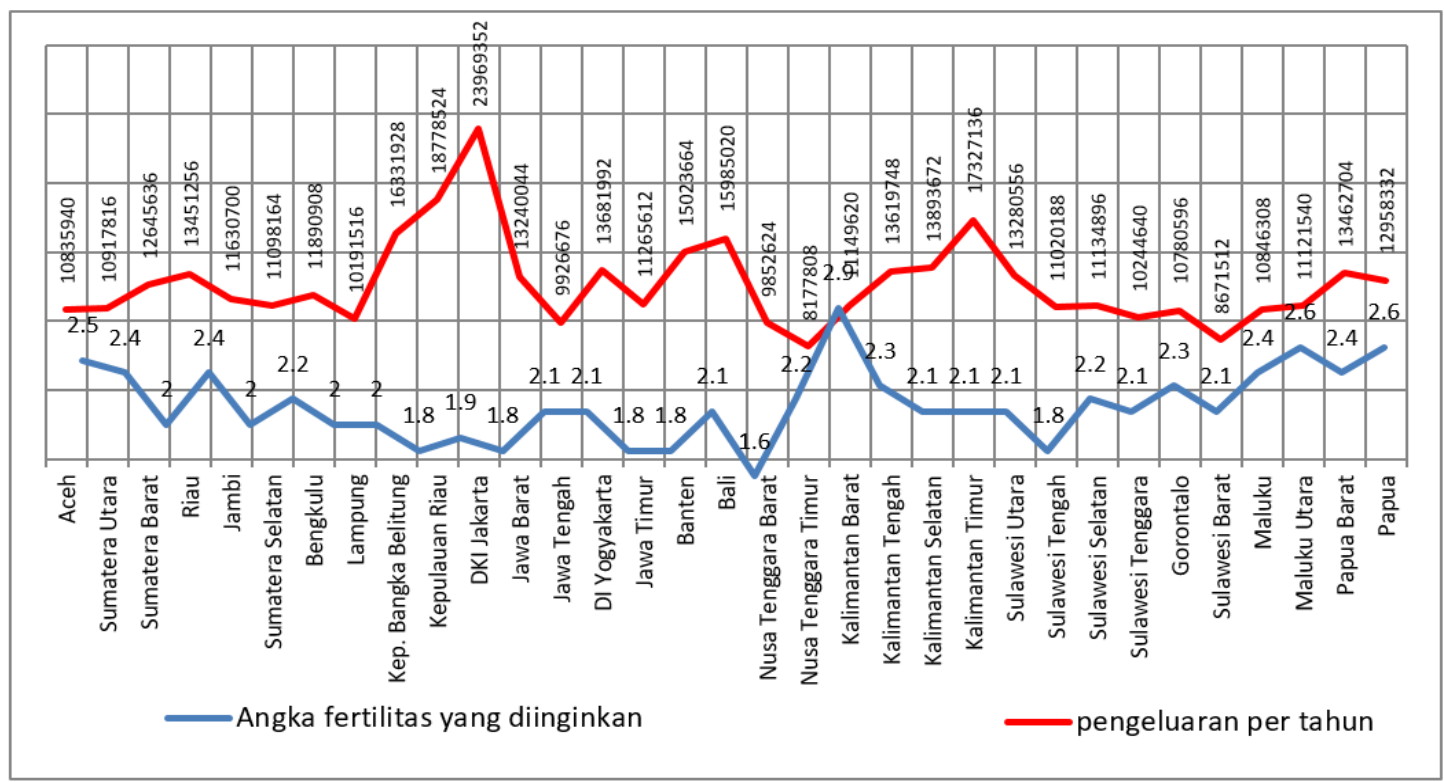

Sumber: BPS (2018a, 2018g)

Selanjutnya dengan memperhatikan hasil analisis korelasi Pearson (Tabel 3), terlihat bahwa hubungan antara pengeluaran per kapita dan jumlah anak yang diinginkan terbukti kuat dan signifikan, dengan arah hubungan yang negatif. Hal ini berarti bahwa pada saat pengeluaran per kapita per tahun semakin tinggi, maka rumah tangga cenderung menurunkan jumlah anak yang diinginkannya, demikian juga sebaliknya jika pengeluaran per kapita per tahun sedikit, maka rumah tangga cenderung menambah jumlah anak yang diinginkannya.

Tabel 3. Hasil analisis korelasi Pearson antara pengeluaran per kapita dan rata-rata jumlah anak yang diinginkan

\begin{tabular}{|c|c|}
\hline Korelasi Pearson & $\begin{array}{c}\text { Rata-rata jumlah anak } \\
\text { yang diinginkan }\end{array}$ \\
\hline Pengeluaran per kapita & $\begin{array}{c}\mathrm{r}=-0,497 \\
\text { sign }=0,003\end{array}$ \\
\hline
\end{tabular}

Dari analisis ini dapat disimpulkan bahwa variabel pengeluaran per kapita per tahun merupakan salah satu faktor yang ikut menentukan rumah tangga dalam memutuskan jumlah anak yang ingin dimilikinya. Dengan adanya anak, situasi ini tentunya berimplikasi pada munculnya proporsi pengeluaran rumah tangga yang dikeluarkan untuk biaya anak. Biaya anak ini tergantung dari kebutuhan masing-masing anak, antara lain meliputi biaya pendidikan, kesehatan, juga biaya pangan dan sandangnya.

\section{Indeks Pembangunan Manusia (IPM)}

IPM Indonesia telah berada pada tingkat yang cukup menggembirakan. Data BPS menunjukkan pada tahun 2017 IPM Indonesia mencapai $70,81 \%$, yaitu capaian pembangunan dengan kategori tinggi. Beberapa provinsi dengan capaian IPM di atas capaian nasional adalah Sumatera Barat $(71,24 \%)$, Riau $(71,79 \%)$, Kepulauan Riau (74,45\%), DKI Jakarta (80,06\%), DI Yogyakarta (78,89\%), Banten (71,42\%), Bali (74,30\%), Kalimantan Timur $(75,12 \%)$, dan Sulawesi Utara $(71,66 \%)$.

IPM mencerminkan capaian pembangunan dengan mempertimbangkan dimensi ekonomi, pendidikan dan kesehatan. Ketiga dimensi ini diasumsikan sangat erat kaitannya dengan penentuan rata-rata jumlah anak yang ingin dimiliki. Hal ini dikarenakan nilai dan biaya anak ditentukan juga oleh faktor ekonomi, pendidikan dan kesehatan. Jika dibandingkan dengan variabel rata-rata jumlah anak yang ingin dimiliki, pola yang terlihat adalah bahwa terjadi hubungan terbalik antara kedua variabel tersebut (Gambar 5). Sebagai contoh, Provinsi Nusa Tenggara Timur memiliki nilai IPM rendah namun 
Jurnal Kependudukan Indonesia | Vol. 14, No. 2, Desember 2019|93-104

rata-rata jumlah anak yang ingin dimiliki sangat besar. Sebaliknya, Provinsi DKI Jakarta memiliki IPM sangat tinggi tapi rata-rata jumlah anak yang ingin dimiliki sangat sedikit.

Gambar 5. IPM dan rata-rata jumlah anak yang diinginkan menurut provinsi, Indonesia, 2017

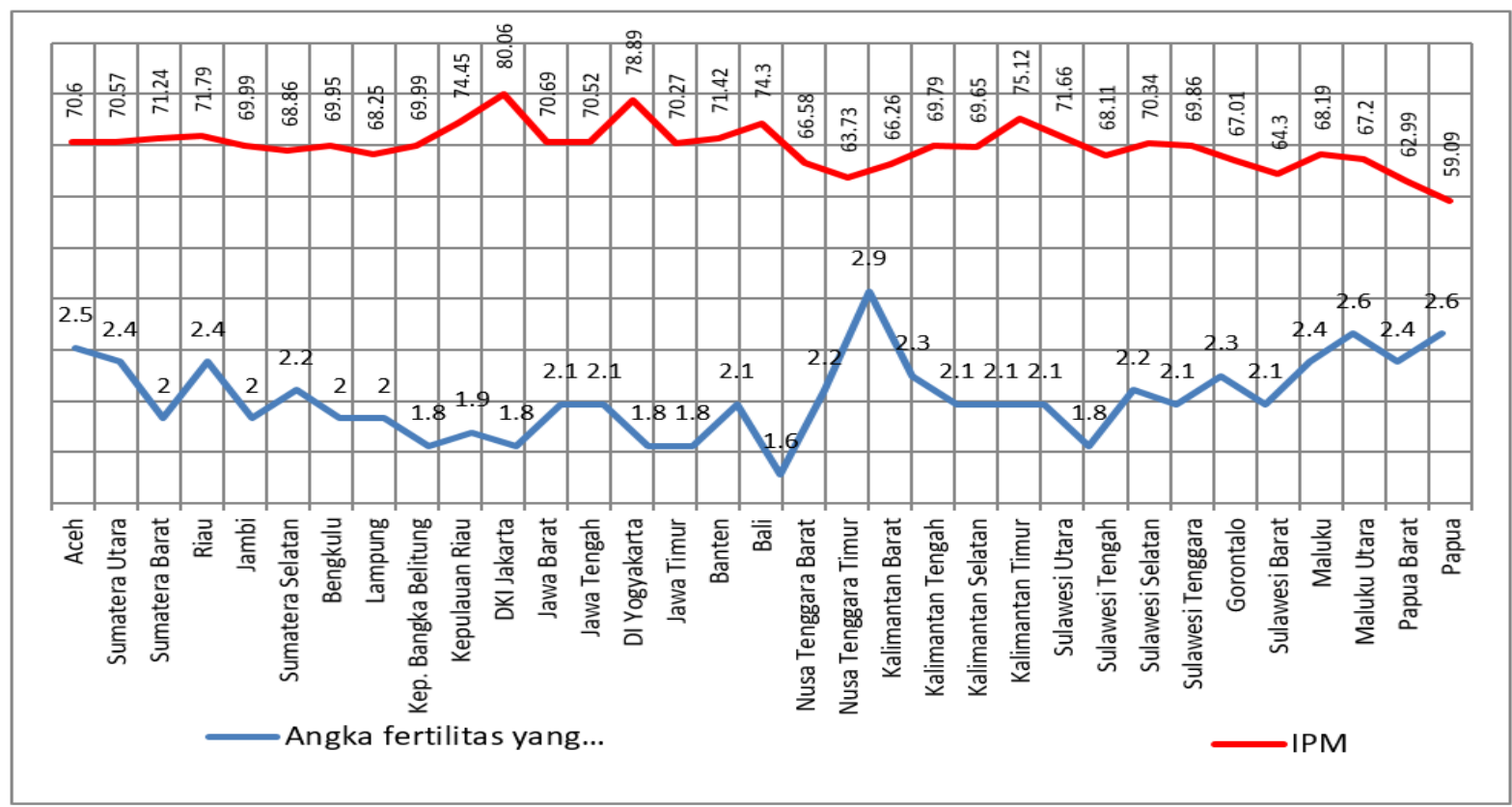

Sumber: BPS (2018a, 2018c)

Analisis dengan menggunakan korelasi Pearson (Tabel 4) menunjukkan bahwa hubungan antara IPM dan ratarata jumlah anak yang diinginkan terbukti secara signifikan saling memengaruhi. Arah hubungan ini bersifat negatif, yang berarti bahwa jika di suatu wilayah memiliki nilai IPM yang tinggi maka rumah tangga cenderung menginginkan jumlah anak yang lebih sedikit. Demikian juga sebaliknya, jika suatu wilayah dengan IPM rendah maka rumah tangga cenderung akan menginginkan jumah anak yang lebih banyak.

Tabel 4. Hasil analisis korelasi Pearson antara IPM dan rata-rata jumlah anak yang diinginkan

\begin{tabular}{|l|c|}
\hline \multicolumn{1}{|c|}{ Korelasi Pearson } & $\begin{array}{c}\text { Rata-rata jumlah anak } \\
\text { yang diinginkan }\end{array}$ \\
\hline $\begin{array}{l}\text { Indeks Pembangunan } \\
\text { Manusia }\end{array}$ & $\mathrm{r}=-0,723$ \\
sign $=0,000$
\end{tabular}

Dari analisis yang telah dilakukan, dapat dinyatakan bahwa IPM merupakan salah satu faktor yang ikut menentukan jumlah anak yang ingin dimiliki oleh suatu rumah tangga. Hampir searah dengan variabel pengeluaran per kapita, variabel IPM ini juga memperhitungkan aspek-aspek penting dalam menentukan biaya anak.

\section{Persentase penduduk miskin}

Jumlah penduduk miskin Indonesia pada semester 1 tahun 2017 sebesar 10,64\% (BPS, 2018d). Beberapa provinsi memiliki persentase penduduk miskin di atas 15 persen, antara lain Aceh (16,89\%), Bengkulu (16,45\%), Nusa Tenggara Barat $(16,07 \%)$, Nusa Tenggara Timur (21,85\%), Gorontalo (17,65\%), Maluku (18,45\%), Papua Barat $(25,10 \%)$ dan Papua $(27,62 \%)$.

Jika dibandingkan antara variabel persentase penduduk miskin dan variabel rata-rata jumlah anak yang diinginkan pada tiap provinsi di Indonesia terlihat bahwa hubungan kedua variabel ini tidak memiliki pola yang linear (Gambar 6). Contohnya, Nusa Tenggara Timur memiliki persentase penduduk miskin cukup besar dan memiliki rata-rata jumlah anak yang diinginkan cukup banyak. Sementara itu, Papua memiliki persentase penduduk miskin paling tinggi namun menginginkan jumlah anak yang sedikit, sedangkan Bali memiliki persentase penduduk miskin yang kecil dan rata-rata jumlah anak yang diinginkan juga sedikit. 
Gambar 6. Persentase penduduk miskin dan rata-rata jumlah anak yang diinginkan menurut provinsi, Indonesia, 2017

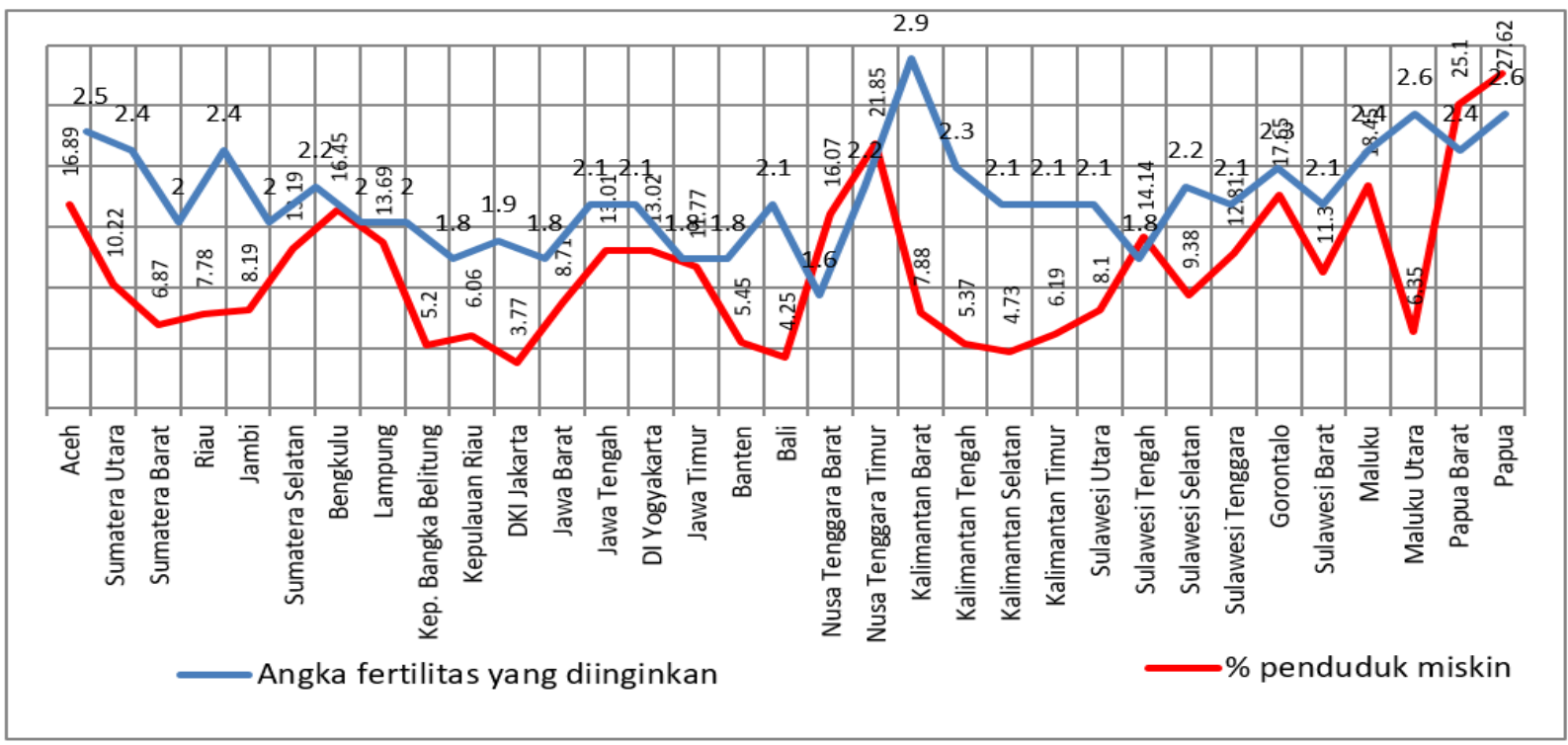

Sumber: BPS (2018a, 2018d)

Analisis korelasi Pearson (Tabel 5) menunjukkan bahwa hubungan antara persentase penduduk miskin dan ratarata jumlah anak yang diinginkan terbukti secara statistik signifikan dan saling memengaruhi. Dapat dicermati bahwa arah hubungan ini bersifat positif, yang berarti bahwa semakin besar persentase penduduk miskin di suatu wilayah, maka semakin banyak jumlah anak yang diinginkan, demikian juga sebaliknya.

Tabel 5. Hasil analisis korelasi Pearson antara persentase penduduk miskin dan rata-rata jumlah anak yang diinginkan

\begin{tabular}{|l|c|}
\hline \multicolumn{1}{|c|}{ Korelasi Pearson } & $\begin{array}{c}\text { Rata-rata jumlah anak } \\
\text { yang diinginkan }\end{array}$ \\
\hline $\begin{array}{l}\text { Persentase penduduk } \\
\text { miskin }\end{array}$ & $\begin{array}{c}\mathrm{r}=-0,668 \\
\text { sign }=0,000\end{array}$ \\
\hline
\end{tabular}

Dari analisis ini dapat dinyatakan bahwa persentase penduduk miskin merupakan salah satu faktor yang ikut menentukan jumlah anak yang ingin dimiliki oleh suatu rumah tangga. Besarnya jumlah penduduk miskin merupakan suatu cerminan dari majunya pembangunan suatu wilayah (Syawie, 2014). Maju atau tidaknya suatu wilayah dapat ditandai dengan semakin pesatnya pembangunan di wilayah tersebut. Seiring dengan kemajuan suatu wilayah, daya tarik wilayah tersebut juga semakin tinggi untuk menarik pendatang dari luar wilayah untuk alasan pekerjaan, pendidikan dan alasan ekonomi lainnya. Semakin maju suatu wilayah, maka semakin banyak penduduk yang datang bermigrasi, namun tidak semua pendatang tersebut dapat terserap oleh lapangan pekerjaan yang ada, akibatnya jumlah penduduk miskin di wilayah tersebut bertambah. Dalam hubungannya dengan jumlah anak yang diinginkan, jika persentase penduduk miskin bertambah, maka jumlah anak yang diinginkan cenderung semakin besar. Hal ini berkaitan dengan nilai anak dari segi ekonomi, sebab anak diharapkan dapat membantu penghasilan keluarga, baik dari sisi tenaga kerja maupun dari sisi materi.

\section{Usia kawin pertama}

Rata-rata usia kawin pertama wanita umur 25-49 tahun adalah 20,8 tahun atau sekitar 20-21 tahun. Median usia kawin pertama berbeda untuk masing-masing provinsi. Meskipun BKKBN telah menetapkan usia kawin pertama untuk wanita minimal adalah 20 tahun, namun pada kenyataannya masih ada wanita yang menikah sebelum memasuki usia 20 tahun. Provinsi dengan median usia kawin pertama di bawah usia 20 tahun antara lain Jambi (19,7 tahun), Kalimantan Tengah (19 tahun) dan Kalimantan Selatan (19,5 tahun).

Perbandingan antara variabel usia kawin pertama dan rata-rata jumlah anak yang diinginkan terlihat pada Gambar 7. Pada gambar tersebut terlihat pola yang berbeda-beda untuk tiap provinsi. Nusa Tenggara Timur memiliki median usia kawin pertama cukup tinggi dan memiliki rata-rata jumlah anak yang diinginkan cukup besar, sedangkan Papua memiliki median usia kawin pertama rendah dan rata-rata jumlah anak yang diinginkan cukup besar. Selanjutnya, Kepulauan Riau memiliki median usia kawin pertama tinggi dan rata-rata jumlah anak yang diinginkan sangat rendah. 
Gambar 7. Usia kawin pertama dan rata-rata jumlah anak yang diinginkan menurut provinsi, Indonesia, 2017

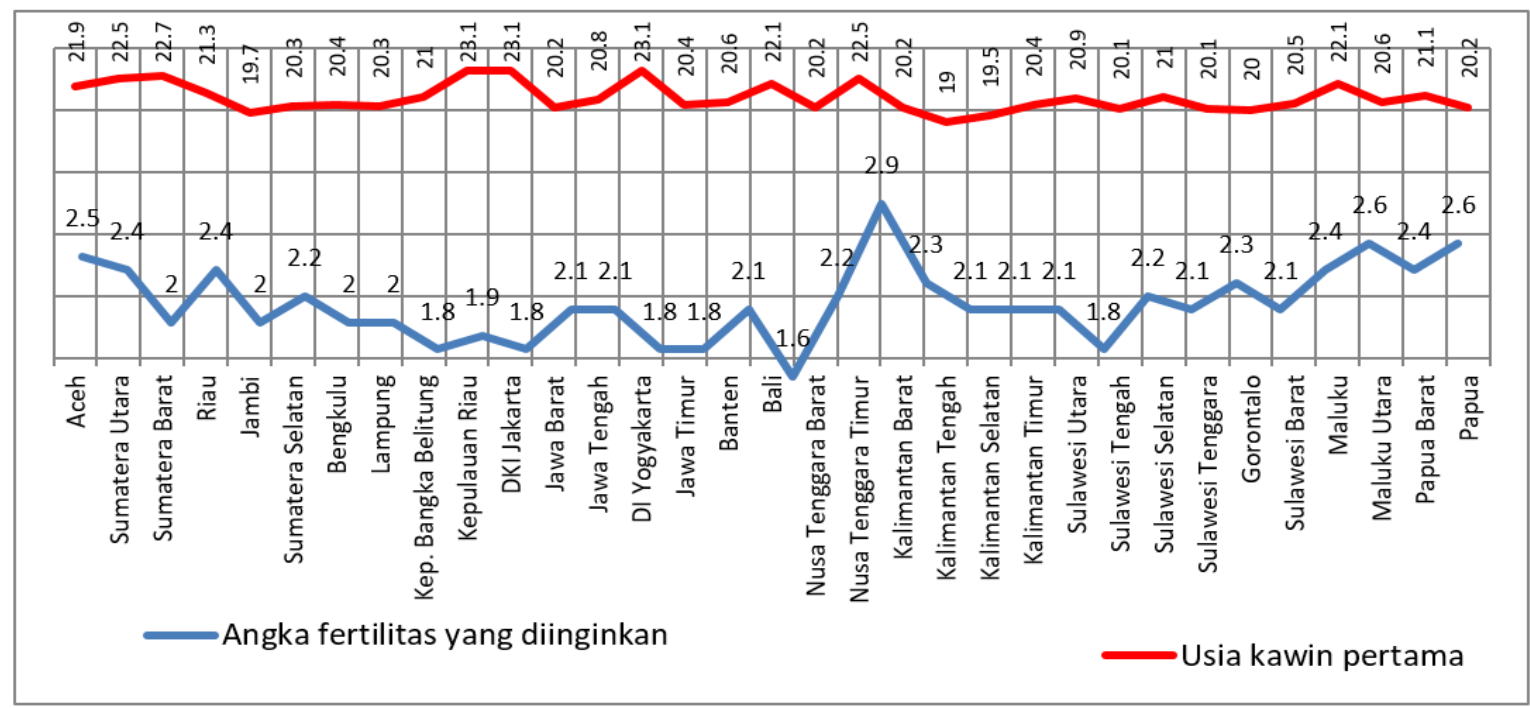

Sumber: BPS (2018a)

Dari hasil analisis korelasi Pearson yang dilakukan (Tabel 6) tampak bahwa hubungan antara usia kawin pertama dan rata-rata jumlah anak yang diinginkan terbukti secara statistik tidak signifikan. Meskipun usia kawin pertama terbukti memengaruhi angka kelahiran total (Hartoyo dkk., 2011), namun ternyata tidak sama pengaruhnya terhadap jumlah anak yang diinginkan. Hal ini dikarenakan tidak semua wanita yang menikah ingin langsung memiliki anak dengan berbagai alasan.

Tabel 6. Hasil analisis korelasi Pearson antara usia kawin pertama dan rata-rata jumlah anak yang diinginkan

\begin{tabular}{|c|c|}
\hline Korelasi Pearson & $\begin{array}{c}\text { Rata-rata jumlah anak } \\
\text { yang diinginkan }\end{array}$ \\
\hline Usia kawin pertama & $\begin{array}{c}\mathrm{r}=-0,053 \\
\text { sign }=0,770\end{array}$ \\
\hline
\end{tabular}

\section{Partisipasi kerja perempuan}

Variabel partisipasi kerja perempuan yang digunakan dalam penelitian ini adalah variabel Tingkat Partisipasi Angkatan Kerja (TPAK) khusus perempuan baik di wilayah perkotaan maupun perdesaan. TPAK merupakan persentase antara jumlah angkatan kerja dibagi dengan jumlah penduduk usia 15 tahun ke atas. TPAK mengindikasikan besarnya persentase usia kerja yang aktif secara ekonomi di suatu negara/wilayah. Semakin tinggi TPAK, semakin tingi pula pasokan tenaga kerja yang tersedia untuk memproduksi barang dan jasa dalam suatu perekonomian. TPAK perempuan di Indonesia tahun 2017 adalah sebesar 50,89\%. Provinsi dengan TPAK terkecil adalah Sulawesi Utara dengan
41,7 persen disusul Kalimantan Timur sebesar 42,33\% dan Banten sebesar 42,8\%, sedangkan TPAK tertinggi adalah Bali sebesar 67,7\% dan Papua sebesar 67,45\%.

Gambar 8 menunjukkan pola hubungan TPAK perempuan dan rata-rata jumlah anak yang diinginkan untuk tiap provinsi. Papua memiliki TPAK dan rata-rata jumlah anak yang diinginkan cukup besar, kemudian Riau dengan TPAK rendah sedangkan rata-rata jumlah anak yang diinginkan cukup besar, selanjutnya Yogyakarta dengan TPAK tinggi sedangkan rata-rata jumlah anak yang diinginkan sangat rendah.

Dari hasil analisis korelasi Pearson (Tabel 7), terlihat bahwa hubungan variabel TPAK perempuan dan ratarata jumlah anak yang diinginkan terbukti secara statistik tidak signifikan saling memengaruhi. Studi terdahulu menyatakan bahwa jumlah tanggungan keluarga berpengaruh positif dan signifikan terhadap keputusan perempuan untuk bekerja (Majid \& Handayani, 2012) Namun, kajian ini menunjukkan bahwa partisipasi perempuan dalam angkatan kerja dan jumlah anak yang diinginkan tidak terbukti saling memengaruhi.

Tabel 7. Hasil analisis korelasi Pearson antara TPAK perempuan dan rata-rata jumlah anak yang diinginkan

\begin{tabular}{|c|c|}
\hline Korelasi Pearson & $\begin{array}{c}\text { Rata-rata jumlah anak } \\
\text { yang diinginkan }\end{array}$ \\
\hline TPAK perempuan & $\mathrm{r}=0,101$ \\
sign $=0,576$
\end{tabular}


Gambar 8. TPAK perempuan dan rata-rata jumlah anak yang diinginkan menurut provinsi, Indonesia, 2017

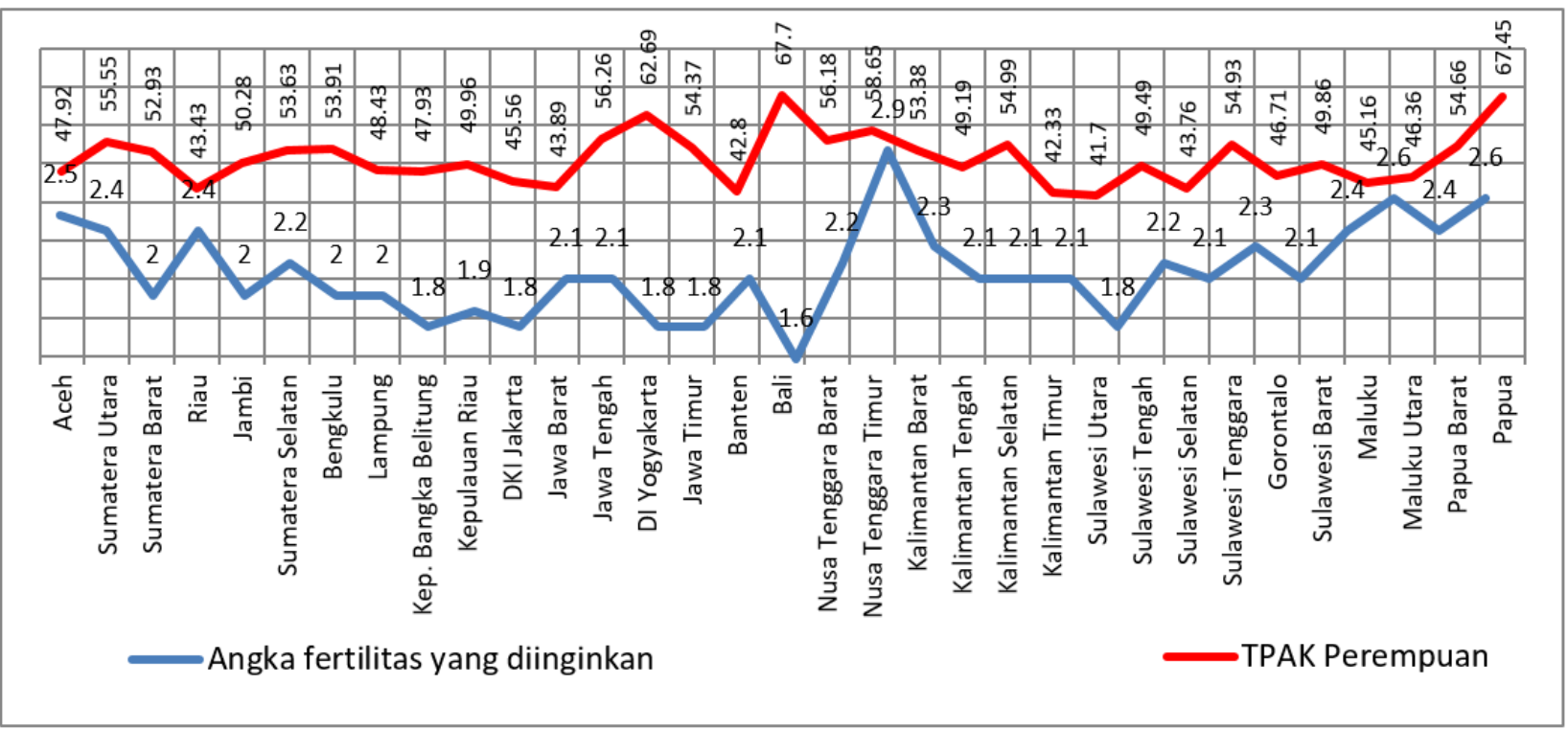

Sumber: BPS (2018a)

\section{KESIMPULAN}

Berdasarkan analisis korelasi yang dilakukan pada penelitian ini, beberapa variabel makro sosioekonomi telah terbukti secara statistik mempengaruhi rata-rata jumlah anak yang diinginkan. Variabel penggunaan kontrasepsi, Indeks Pembangunan Manusia (IPM), persentase penduduk miskin dan pengeluaran per kapita terbukti secara statistik memengaruhi rata-rata jumlah anak yang diinginkan.

Variabel penggunaan kontrasepsi, Indeks Pembangunan Manusia (IPM) dan pengeluaran per kapita memiliki arah hubungan yang negatif. Sementara itu, variabel persentase penduduk miskin memiliki arah hubungan yang positif. Dengan kata lain, hasil analisis ini mengindikasikan bahwa jika penggunaan kontrasepsi besar, atau jika nilai IPM tinggi, atau jika pengeluaran per kapita per tahun meningkat, maka rumah tangga cenderung menginginkan jumlah anak yang lebih sedikit. Hal yang berbeda ditemukan pada variabel persentase penduduk miskin yang memiliki hubungan yang positif dengan variabel rata-rata jumlah anak yang diinginkan. Hal ini berarti bahwa jika persentase penduduk miskin bertambah maka rata-rata jumlah anak yang diinginkan justru mengalami peningkatan, begitu pun sebaliknya.

Keputusan seseorang untuk menentukan jumlah anak yang diinginkannya semakin kompleks pada masa sekarang ini. Pertimbangan terkait jumlah anak bukan lagi hanya berdasarkan kultur atau kebiasaan setempat, melainkan sudah mulai mempertimbangkan faktor lain yang lebih luas. Perlu pula dipikirkan bahwa tuntutan zaman masa kini dan masa depan menjadi hal yang tidak dapat dihindari lagi. Hasil penelitian ini membuktikan bahwa variabel makro sosio-ekonomi juga turut menentukan seseorang menentukan jumlah anak yang diinginkan. Anak dipandang bukan lagi dari sisi kuantitas saja, melainkan juga dari sisi kualitasnya. Globalisasi dan kemajuan teknologi menuntut setiap anak untuk dapat bersaing di ranah nasional maupun dunia. Hal tersebut yang akhirnya merubah gaya hidup dan tuntutan di level paling kecil yaitu keluarga.

\section{DAFTAR PUSTAKA}

Badan Pusat Statistik [BPS]. (2018a). Angka fertilitas total menurut provinsi 1971, 1980, 1990, 1991, 1994, 1997, 2000, 2002, 2007, 2010 dan 2012. https://www.bps.go.id/statictable/2009/02/20/127 1/angka-fertilitas-total-menurut-provinsi-19711980-1985-1990-1991-1994-1997-1998-19992000-2002-2007-2010-dan-2012.html

(2018b). PDRB atas dasar harga berlaku tahunan menurut 52 lapangan usaha. https://sirusa.bps.go.id/sirusa/ index.php/variabel/7804

. (2018c). Indeks pembangunan manusia menurut provinsi, 2010-2017 (Metode baru). https://www.bps.go.id/dynamictable/2016/06/16/ 1211/indeks-pembangunan-manusia-menurutprovinsi-2010-2017-metode-baru-.html 
Jurnal Kependudukan Indonesia | Vol. 14, No. 2, Desember 2019|93-104

(2018d). Persentase penduduk miskin menurut provinsi 2007-2018. https://www.bps.go. id/dynamictable/2016/08/18/1219/persentasependuduk-miskin-menurut-provinsi-2007--2018.html

(2018e). Persentase rata-rata pengeluaran per kapita menurut kelompok komoditi. https://sirusa.bps.go.id/sirusa/index.php/ indikator/1106

(2018f). Produk domestik regional bruto atas dasar harga berlaku menurut provinsi, 2010-2017 (miliar rupiah). https://www.bps.go.id/ dynamictable/2015/10/07/955/-seri-2010-produkdomestik-regional-bruto-atas-dasar-hargaberlaku-menurut-provinsi-2010-2017-miliarrupiah-.html

(2018g). Rata-rata pengeluaran per kapita sebulan di daerah perkotaan dan perdesaan menurut provinsi dan kelompok barang (rupiah), 2011-2017. https://www.bps.go.id/statictable/ 2014/09/08/945/rata-rata-pengeluaran-per-kapitasebulan-di-daerah-perkotaan-dan-perdesaanmenurut-provinsi-dan-kelompok-barang-rupiah2011-2017.html

Badan Perencanaan Pembangunan Nasional [Bappenas], BPS, \& United Nations Population Fund [UNFPA]. (2013). Proyeksi Penduduk Indonesia (Indonesia Population Projection) 2010-2035. BPS.

Badan Kependudukan dan Keluarga Berencana Nasional [BKKBN]. (2015). Rencana strategis Badan Kependudukan dan Keluarga Berencana Nasional Tahun 2015-2019. BKKBN.

BKKBN, BPS, Kementerian Kesehatan., \& United States Agency for International Development [USAID]. (2018). Survei demografi dan kesehatan Indonesia 2017. BKKBN, BPS, Kementerian Kesehatan \& USAID.

Bongaarts, J. (1993). The supply-demand framework for the determinants of fertility: An alternative implementation. Population Studies, 47(3), 437456. www.jstor.org/stable/2175127

Burns, R. B. (1939). Introduction to research methods. Addison Wesley Longman.

Fatchiati, N. (2015, Juli 6). KB, gaya hidup keluarga Indonesia. https://cpps.ugm.ac.id/kb-gaya-hidupkeluarga-indonesia-oleh-litbang-kompas/
Hartoyo, Latifah, M., \& Mulyani, S. R. (2011). Studi nilai anak, jumlah anak yang diinginkan, dan keikutsertaan orang tua dalam program KB. Jurnal Ilmu Keluarga \& Konsumen, 4(1), 37-45. https://doi.org/10.24156/jikk.2011.4.1.37

Heryanah. (2015). Ageing population dan bonus demografi kedua di Indonesia. Populasi, 23(2), 116. https://doi.org/10.22146/jp.15692

Ihromi, T.O. (1999). Bunga rampai sosiologi keluarga. Yayasan Obor Indonesia.

Kashalala, G. T., \& Koch, S. F. (2014). The economic approach to fertility: A causal mediation analysis. https://www.up.ac.za/media/shared/61/WP/wp_2 014_34.zp39438.pdf

Majid, F., \& Handayani, H. R. (2012). Faktor-faktor yang mempengaruhi keputusan perempuan berstatus menikah untuk bekerja (Studi kasus Kota Semarang). Diponegoro Journal of Economics, l(1), 1-9. https://ejournal3.undip.ac.id/index.php/ jme/article/view/410/410

National Research Council. (1982). Determinants of fertility in developing countries: An overview and a research agenda. The National Academies Press. https://doi.org/10.17226/19589

(1983). Fertility decline in Indonesia: Analysis and interpretation. The National Academies Press. https://doi.org/ $10.17226 / 19455$.

Putro, D. A., \& Listyaningsih, U. (2017). Unmet need Keluarga Berencana di daerah perkotaan dan perdesaan di Provinsi Daerah Istimewa Yogyakarta. Jurnal Bumi Indonesia, 6(4). http://lib.geo.ugm.ac.id/ojs/index.php/jbi/article/v iew/903/876

Siregar, F. A. (2003). Pengaruh nilai dan jumlah anak pada keluarga terhadap Norma Keluarga kecil Bahagia dan Sejahtera (NKKBS). http://repository.usu.ac.id/bitstream/handle/12345 6789/3751/fkmfazidah2.pdf?sequence $=1 \&$ is Allowed $=y$

Syawie, M. (2014). Pembangunan yang menyejahterakan masyarakat Indonesia: Sebuah kajian konsep. Sosio Informa, 19(3), 191-204. https://doi.org/10.33007/inf.v19i3.99 